\title{
Застосування методу балонної дермотензії в лікуванні уроджених гігантських пігментних невусів у дітей
}

\begin{abstract}
Мета роботи: покращення онкологічних, функціональних та косметичних результатів лікування дітей з уродженими гігантськими пігментними невусами із використанням розтягнутих місцевих клаптів шляхом дермотензії.

Матеріали і методи. У відділенні онкогематології Вінницької обласної дитячої клінічної лікарні в період із 2014 по 2019 рр. оперовані 286 дітей віком від 1 до 18 років з уродженими пігментними невусами різної локалізації та розмірів. У цих дітей було проведено 318 оперативних втручань, що було зумовлено часткою уроджених гігантських пігментних невусів та неможливістю повного їх видалення одноетапним оперативним втручанням у 12 пацієнтів. В цій групі дітей, віком від 3 до 12 років, метод ендоекспандерної дермотензії застосовували за необхідності пластики значного за площею дефекту шкіри.

Результати досліджень та їх обговорення. В усіх 12 клінічних випадках ми отримали задовільні косметичні та функціональні результати без ознак порушення мікроциркуляції пасма шкіри на всіх етапах лікування. Морфологічні дослідження на етапах лікування виявляли незначні зміни в епідермісі. УзД в режимі кольорового доплерівського картування виявило, що в процесі проведення експандерної дермотензії перфузія шкіри не зменшувалась, а збільшувалась, що свідчить про участь в експансії судин шкіри.
\end{abstract}

Ключові слова: метод балонної дермотензії; уроджений гігантський пігментний невус.

Постановка проблеми і аналіз останніх досліджень та публікацій. Можливості реконструктивної хірургії в деяких анатомічних ділянках часто обмежені через відсутність придатних для пластики тканин. Певним проривом у вирішенні цієї проблеми є застосування методу балонного розтягнення, важливою перевагою якого є можливість додаткового збільшення поверхні суміжних непошкоджених тканин із наступним ефективним їх використанням у якості пластичного матеріалу. Метод балонної дермотензії дозволяє відновлювати шкірні покриви, які ідентичні за кольором, текстурою та еластичністю оточуючим тканинам. На думку деяких дослідників, тканинному відновленню можуть підлягати навіть великі площі шкіри, за рахунок використання повторних етапів дерматензії, що дозволяє досягти задовільних косметичних та функціональних результатів без створення додаткових донорських деформацій [1, 3, 4].

В останні роки в реконструктивно-відновній хірургії дитячого віку, при лікуванні уроджених гігантських пігментних невусів, які потребують багаторічного етапного лікування, застосовується метод балонної дермотензії, який вперше запропонували американські дослідники А. Радован та Ч. Ньюмен (1957) [1].

У вітчизняній та закордонній літературі наявні лише поодинокі повідомлення щодо застосування балонного, особливо повторного (етапного), розтягнення при лікуванні уроджених гігантських пігментних невусів в дитячому віці. Проведені експериментальні та клінічні дослідження розтягнутих шкірних клаптів довели, що при дермотензії перфузія шкіри збільшується, а кровопостачання у сформованих клаптях відбувається за рахунок збільшення васкуляризації граничних ділянок та новоутворення судин у клаптях, їх адаптації до розтягнення та утворення із них судинно-тканинної капсули вже через декілька днів після початку експансії [2, 5, 6].

Однак відсутність даних стосовно системного застосування даного методу лікування уроджених гігантських пігментних невусів в педіатричній практиці, певна невизначеність щодо чітких показів та протипоказів до дермотензії, недостатня кількість клінічного матеріалу визначає актуальність даної проблеми.

Мета роботи: покращення онкологічних, функціональних та косметичних результатів лікування дітей з уродженими гігантськими пігментними невусами із використанням розтягнутих місцевих клаптів шляхом дермотензії.

Матеріали і методи. У відділенні онкогематології Вінницької обласної дитячої клінічної лікарні в період із 2014 по 2019 рр. оперовано 286 дітей віком від 1 до 18 років з уродженими пігментними невусами різної локалізації та розмірів. У всіх цих дітей було проведено 318 оперативних втручань, що було зумовлено часткою уроджених гігантських пігментних невусів та неможливістю повного їх видалення за одне оперативне втручан- 
ня у 12 пацієнтів. В цій групі дітей, віком від 3 до 12 років, метод ендоекспандерної дермотензії застосовували за необхідності пластику значного за площею дефекту шкіри. Метод заснований на створенні надлишку незміненої шкіри в ділянці, яка безпосередньо межує з невусом та складався із трьох етапів: перший - імплантація експандеру; другий - етап дермотензії; третій - видалення експандеру із повним або частковим видаленням невусу та пластикою дефекту шкіри зміщеним шкірним клаптем. Серед 12 дітей невус мав локалізацію в 8 випадках та тулубі, а в 4 на нижніх кінцівках. Необхідний розмір експандеру в доопераційному періоді визначали із урахуванням від об’єму запланованого оперативного втручання, анатомічної локалізації патологічного утворення та площі незміненої шкіри в ділянці, що безпосередньо межує із невусом.

При етапному видаленні уродженого гігантського пігментного невусу кожне оперативне втручання супроводжували обов'язковим гістологічним дослідженням видаленого фрагмента пігментного невуса з метою вивчення морфологічних змін, що відбувались в епідермісі та судинах шкіри.

Результати досліджень та їх обговорення. При відборі пацієнтів із уродженими гігантськими пігментними невусами на проведення ендоекспандерної дермотензії проводили диференційний діагноз із схожими пігментними утвореннями, а саме: плямами типу “кава з молоком”, уродженим невусом Беккера, хворобою Реклінгхаузена (уроджений нейрофіброматоз), розложистих папіломатозних т.п.

Практичний досвід, який ми набули в процесі виконання даного клінічного дослідження, визначив доцільність застосування методу експандерної дермотензії у пацієнтів віком 3-х років і старше. Це пов'язано з тим, що товщина шкіри та підшкірно-жирової клітковини, а також функціональний стан їх мікроциркуляції у дітей старшої вікової групи забезпечує більшу стійкість тканин до дермотензії, що певною мірою запобігає ускладненням методики.

Спираючись на фактичний аналіз власних результатів лікування, ми сформулювали певні рекомендації щодо профілактики ускладнень при імплантації еспандерів та догляду за ними в період проведення балонної дермотензії:

1. Безпосередньо перед імплантацією експандерів необхідно провести санацію хронічних вогнищ інфекції.

2. Ретельний індивідуальний підбір розміру експандеру із урахуванням розмірів невусу та йо- го локалізації. При цьому слід уникати певних локалізацій патологічного утворення на передній черевній стінці, внутрішніх поверхнях плеча та стегна, проекції суглобів.

3. Основу еспандеру необхідно розташовувати над щільними тканинами (м’язами, кістками тощо). Розріз шкіри повинен бути у перпендикулярному напрямку до напрямку розтягнення. Розташування порожнини для постановки еспандеру повинно бути під фасцією, платизмою або апоневротичним шоломом, а її розміри повинні перевищувати площу основи еспандеру на 1,5-2,0 см. Формування порожнини та постановка еспандеру повинно відбуватись лише під візуальним контролем, в тому числі ендоскопічно, з метою забезпечення адекватного гемостазу та попередження можливості пошкодження еспандеру або приймального порту хірургічним інструментарієм. Після постановки еспандеру порожнина повинна містити дренаж, за показами активний, так як зовнішнє розташування порту - можливий шлях до інфікування всієї порожнини. 3 метою профілактики вторинного інфікування в післяопераційному періоді обов'язкове призначення десенсибілізуючої терапії та антибіотиків широкого спектра дії.

4. Початок розтягнення еспандеру доцільно починати не раніше 7-10 днів після імплантації, а введення в його порожнину рідини проводити з інтервалами в 3-4 дні, тонкою (інсуліновою) голкою, не більше 10-15 \% об’ єму еспандеру на одне введення з метою профілактики надмірного перерозтягнення шкіри та формування атрофічних рубців.

При виконанні III етапу методу експандерної дермотензії, а саме перед висіченням тканин, які підлягали заміщенню, ми обов’язково виконували попереднє викроювання розтягнутої шкіри, оцінка можливостей його зміщення без надлишкового натягу та чітке визначення із відповідним маркуванням меж такого висічення з урахуванням рефракції розтягнутих тканин.

В усіх 12 клінічних випадках ми отримали задовільні косметичні та функціональні результати без ознак порушення мікроциркуляції пасма шкіри на всіх етапах лікування.

Морфологічні дослідження на етапах лікування виявляли незначні зміни в епідермісі. УЗД в режимі кольорового доплерівського картування виявило, що в процесі проведення експандерної дермотензії перфузія шкіри не зменшувалась, а збільшувалась, що свідчить про участь в експансії судин шкіри.

При аналізі отриманих морфо-структурних змін судин шкіри ми підтримуємо припущення Р. А. Хагурова із співав. (2016), що саме судинна система є провідним фактором, який визначає 


\section{З ДОСВІДУ РОБОТИ}

ступінь розтягнення м'яких тканин. Дослідники, на основі того, що вже через декілька днів після початку експансії відбувається збільшення кількості артеріол та венул, визначають, що кровопостачання в шкірному клапті, який формується за допомогою експандеру, відбувається за рахунок збільшення васкуляризації приграничних областей та новоутворення судин в клапті, їх адаптації до розтягнення та утворення із них судинно-тканинної капсули [2].

Клінічний випадок. Хворий Я., вік 3 роки, MKCX № 2685, 05.03.2019 р., госпіталізований в відділення онкогематології ВОДКЛ з діагнозом: уроджений гігантський пігментний невус в ділянці спини. На першому етапі лікування, після ви-

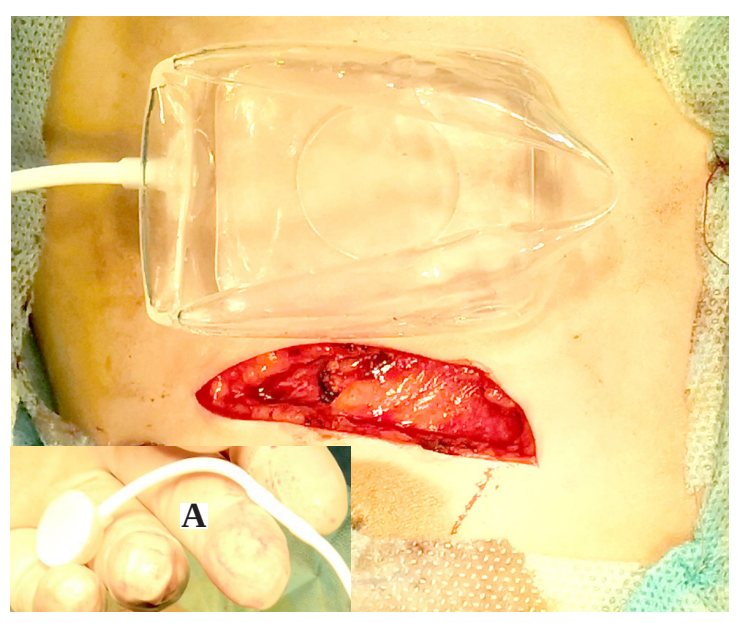

I значення оптимально місця, був встановлений силіконовий експандер відповідного об’єму (рис. 1).

Заповнення експандеру почали на 14 добу післяопераційного періоду, після зняття швів. Експансію виконували за допомогою стерильного фізіологічного розчину двічі на тиждень в об'ємі 10-20 мл під контролем доплерівської флоуметрії.

Через 2 місяці після імплантації експандеру було досягнуто максимального його об’єму та створений необхідний запас пластичного матеріалу. Одразу було виконано другий етап оперативного лікування: видалення тканинного ендоекспандеру, висічення пігментного невусу та пластика шкіри місцевими тканинами із дренуванням ложа рани (рис. 2).

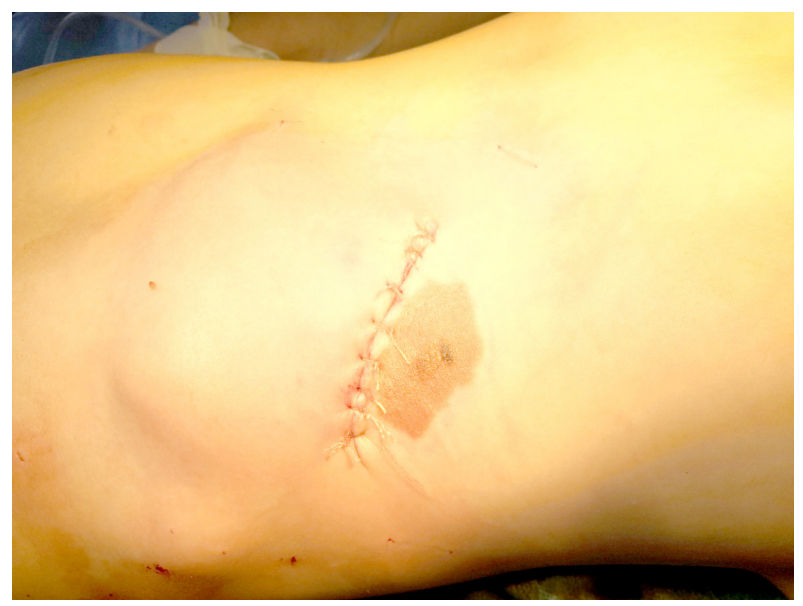

II

Рис. 1. Хворий Я., вік 3 роки, МКСХ № 2685. Етапи першого оперативного втручання. I - формування шкірно-підшкірного доступу перед імплантацією експандеру, А - впускний клапан на проксимальному кінці експандеру; II - загальний вигляд ділянки післяопераційного втручання.

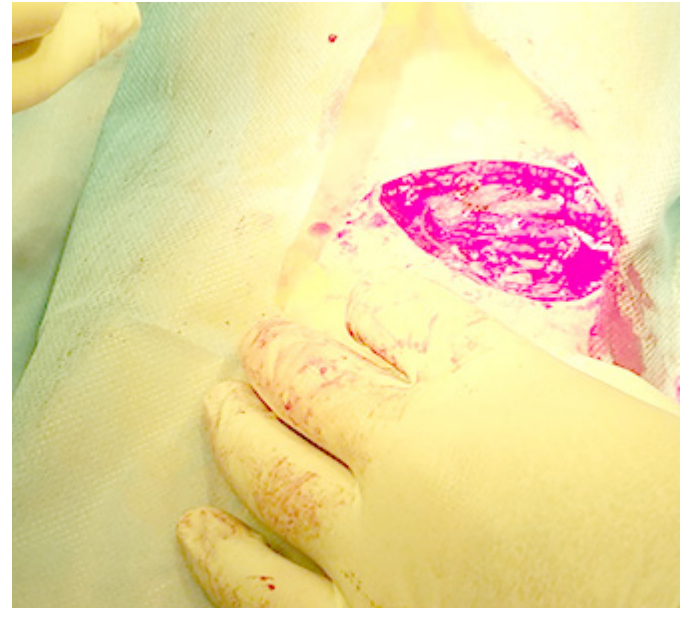

I

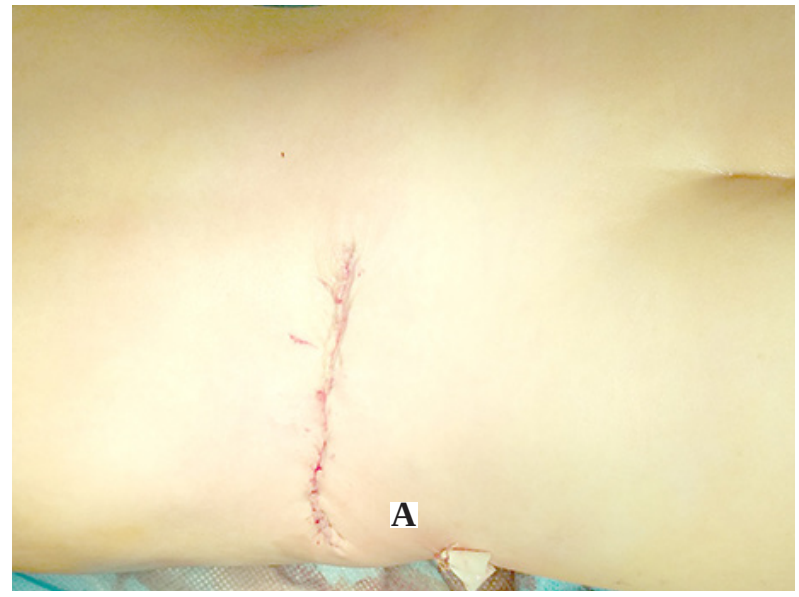

II

Рис. 2. Хворий Я., вік 3 роки, МКСХ № 5976. Етапи другого оперативного втручання. I - загальний вигляд рани після видалення експандеру та висічення невусу; II - загальний вигляд післяопераційної рани 3 накладеним косметичним швом шкіри, А - окремий гумовий дренаж до ложа рани. 
Накладання шкірного шва відбулось без надлишкового натяжіння країв рани та за повної відсутності порушень мікроциркуляції з боку шкіри.

При морфологічному дослідженні видалених біоптатів шкіри на межі із тканиною пігментного невусу до початку та після проведення балонної дерматензії визначені наступні спільні особливості.

Гнізда невусних клітин визначались на межі епідермісу та дерми в області вершин гребеня сітчастого шару шкіри. Також невусні клітини розташовувались внутрішньодермально у вигляді гнізд, тяжів, інколи поодинці серед вираженої фіброзної тканини дерми. У деяких випадках невус-

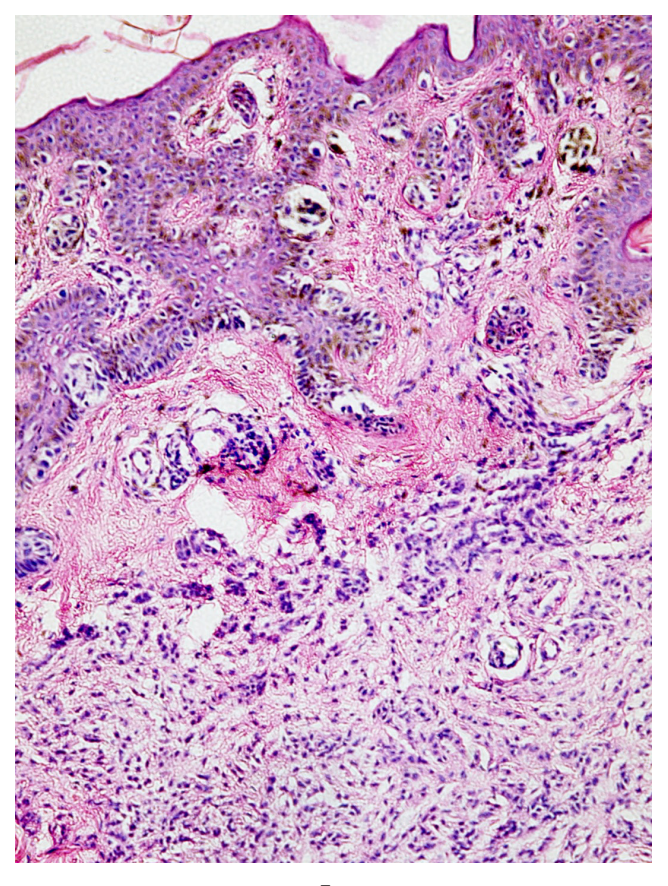

I ні клітини розташовувались у вигляді “острівців” компактної маси. Невусні клітини містили різну кількість пігменту, концентрація якого була більше у верхніх шарах невуса. Серед невусних клітин нерідко визначались гігантські багатоядерні клітини. В базальних шарах епідермісу характерним було визначення лінійної проліферації меланоцитів. В обох випадках морфологічна картина відповідала будові змішаного невусу.

Відмінність в гістологічній будові шкіри на межі з тканиною невусу після проведення балонної дерматензії полягала в кількісному збільшенні вен і артеріол та новоутворених судин (рис. 3).

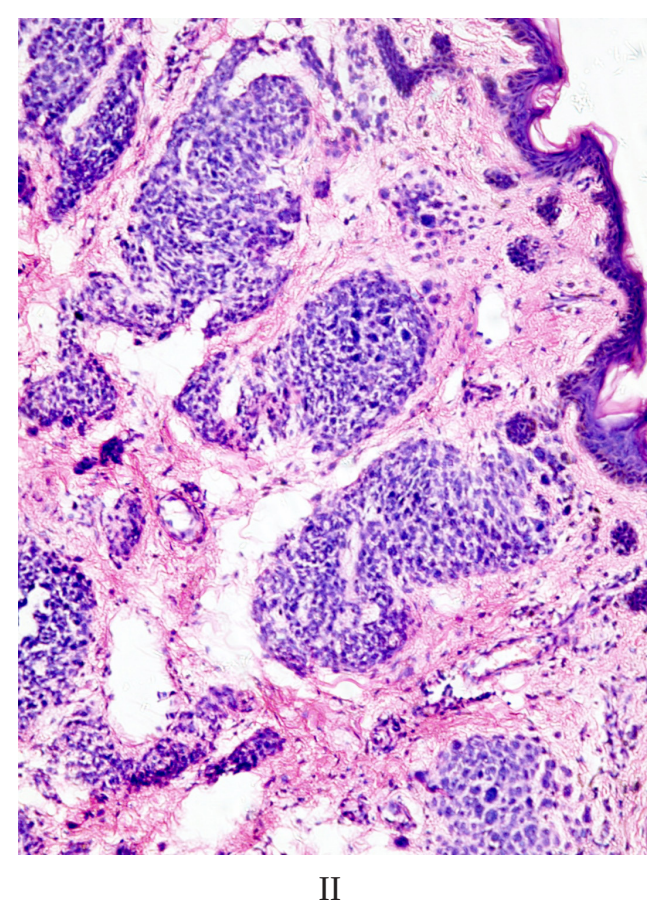

Рис. 3. Хворий Я., вік 3 роки. Морфологічна будова шкіри на межі з тканиною пігментного невусу: I - до початку та II - після проведення балонної дерматензії (збільшення кількості судин мікроциркуляторного русла). Забарвлення гематоксилін та еозин. $\times 100$.

Післяопераційний період у пацієнта мав задовільний перебіг.

При контрольному огляді через 3 місяці визначається гарний косметичний та функціональний ефекти.

Висновки. Методика експандерної дерматензії у дітей є досконалим, високоефективним та оптимальним способом відновлення ціліснос- ті шкіри, що дозволяє повністю або частково, але великими площами видаляти уроджені гігантськи пігменті невуси на тулубі та в зонах складної анатомічної локалізації при наявності достатньої ділянки незміненої шкіри. Дотримання запропонованих рекомендацій проведення методики балонної дерматензії дозволяє уникати періопераційних ускладнень в усі терміни проведення лікування. 


\section{СПИСОК ЛІТЕРАТУРИ}

1. Морфологическая оценка компенсаторных возможностей клеток кожи волосистой части головы при этапной дермотензии / И. А. Чекмарева, О. В. Паклина, В. И. Шаробаро [и др.] // Гены \& Клетки. - 2014. - Т. IX, № 2. - С. 76-79.

2. Применение метода баллонной дерматензии в детской реконструктивно-пластической хирургии / Р. А. Хагуров, А. В. Александров, В. В. Рыбченок [и др.] // Вестник РГМУ. - 2016. - № 5. - C. 34-38.

3. Jain S. Dermatology / S. Jain. - Springer Science+Business Media; 2012. - 369 p.

\section{REFERENCES}

1. Chekmareva, I.A., Paklina, O.V., Sharobaro, V.I., Vaganova, N.A., Gordienko, E.N., Vaganov, N.V. \& Grechishnikov, M.I. (2014). Morfologicheskaya otsenka kompensatornykh vozmozhnostey kletok kozhi volosistoy chasti golovy pri etapnoy dermototenzii [Morphologic assessment of compensatory abilities of scalp skin cells in staged dermotensia]. Geny \& Kletki - Genes and Cells, IX (2), 76-79 [in Russian].

2. Khagurov, R.A., Aleksandrov, A.V., Ribchenok, V.V., Samorukova, N.N., Velskaya, Yu.I., Lvov, N.V., \& Koval, S. Yu. (2016). Primenenie metoda ballonnoy dermatenzii v detskoy rekonstruktivno-plasticheskoy khirurgii [Application of the balloon skin expansion method in pediatric reconstructive
4. Skin of patients with large/giant congenital melanocytic nevi shows increased mast cells / C. M. Salgado, R. B. Silver, B. S. Bauer, D. Basu // Pediatric and Developmental Pathology. 2014. - No. 3. - P. 221-223.

5. Sinikumpu S.-P. Skin diseases and their association with systemic diseases in the northern Finland Birth Cohort 1966 / S.-P. Sinikumpu. - UNIVERSITY OF OULU, OULU; 2018. - 93 p. 6. Viana A. Giant congenital melanocytic nevus / A. Viana, B. Gontijo, F. V. Bittencourt // An Bras. Dermatol. - 2013. Vol. 88 (6). - P. 863-878. surgery]. Vestnik RGMU - Bulletin of RSMU, 5, 34-38 [in Russian].

3. Jain, S. (2012). Dermatology. Springer Science+Business Media. 4. Salgado, C.M., Silver, R.B., Bauer, B.S., \& Basu, D. (2014). Skin of patients with large/giant congenital melanocytic nevi shows increased mast cells. Pediatric and Developmental Pathology, 3, 221-223.

5. Sinikumpu, S.-P. (2018). Skin diseases and their association with systemic diseases in the northern Finland Birth Cohort 1966. UNIVERSITY OF OULU.

6. Viana, A., Gontijo, B., \& Bittencourt, F.V. (2013). Giant congenital melanocytic nevus. An Bras. Dermatol., 88 (6), 863-878.

Отримано 26.11.2019

Електронна адреса для листування: zedmaxstorm7@gmail.com

\section{S. KONOPLITSKIY, O. V. PASECHNYK, O. O. KALYNCHUK, D. V. KONOPLITSKIY, R. V. SHAVLIUK}

M. Pyrohov Vinnytsia National Medical University

\section{APPLICATION OF BALLOON DERMATENSIA METHOD IN TREATMENT OF CONGENITAL GIANT PIGMENTED NEVI IN CHILDREN}

The aim of the work: to improve the oncological, functional and cosmetic results of the treatment of children with congenital giant pigmented nevi using stretched local flaps by means of dermatensia.

Materials and Methods. In the Oncohematology Department of the Vinnytsia Regional Children's Clinical Hospital, from 2014 to 2019, 286 children aged 1 to 18 years with congenital pigmented nevi of various localization and sizes were operated on. In all these children, 318 surgical interventions were performed, which was due to the proportion of congenital giant pigmented nevi and the impossibility of their complete removal in one surgical intervention in 12 patients. In this group of children aged 3 to 12 years, the method of endoexpander dermatotension was used, if necessary, with plastics of a significant area of skin defect.

Results and Discussion. In all 12 clinical cases, we obtained satisfactory cosmetic and functional results without signs of a violation of the microcirculation of the skin strand at all stages of treatment. Morphological studies at the treatment stages showed minor changes in the epidermis. Ultrasound in the mode of color Doppler mapping revealed that during the expander dermatensia, skin perfusion did not decrease, but increased, which indicates participation in the expansion of blood vessels of the skin.

Key words: balloon dermatensia method; congenital giant pigmented nevus. 
В. С. КОНОПЛИЦКИЙ, О. В. ПАСЕЧНИК, О. О. КАЛИНЧУК, Д. В. КОНОПЛИЦЬКИЙ, Р. В. ШАВЛЮК

Винницкий национальный медицинский университет имени Н. И. Пирогова

\section{ИСПО.ЛЬОВАНИЕ МЕТОДА БА.ЛОННОЙ ДЕРМАТЕНЗИИ В .ЕЧЕНИИ ГИГАНТСКИХ ПИГМЕНТНЫХ НЕВУСОВ У ДЕТЕЙ}

Цель работы: улучшение онкологических, функциональных и косметических результатов лечения детей с врожденными гигантскими пигментными невусами с использованием растянутых местных лоскутов путем дерматензии.

Материалы и методы. В отделении онкогематологии Винницкой областной детской клинической больницы в период с 2014 по 2019 гг. оперированы 286 детей в возрасте от 1 до 18 лет с врожденными пигментными невусами различной локализации и размеров. Во всех этих детей было проведено 318 оперативных вмешательств, что было обусловлено долей врожденных гигантских пигментных невусов и невозможностью полного их удаления за одно оперативное вмешательство у 12 пациентов. В этой группе детей в возрасте от 3 до 12 лет метод эндоэкспандерной дерматензии применяли при необходимости пластики значительного по площади дефекта кожи.

Результаты исследований и их обсуждение. Во всех 12 клинических случаях нами получены удовлетворительные косметические и функциональные результаты без признаков нарушения микроциркуляции пряди кожи на всех этапах лечения.

Морфологические исследования на этапах лечения проявляли незначительные изменения в эпидермисе. УзИ в режиме цветного допплеровского картирования выявило, что в процессе проведения экспандерной дерматензии перфузия кожи не уменьшалась, а увеличивалась, что свидетельствует об участии в экспансии сосудов кожи.

Ключевые слова: метод баллонной дерматензии; врожденный гигантский пигментный невус. 